\title{
"Ekologisen tasapainon" tarina
}

\author{
Yrjö Haila
}

Ihmisen ja luonnon suhde on keskeisimpiä ihmiskunnan tulevaisuuden värittäjiä, ja värit ovat mustaan vivahtavia. Kun ihmisen ja luonnon suhteelle pohditaan tulevaisuuden varalta ihannetilaa, otetaan kriteeriksi yleensä tasapaino. Luonnossa vallitsee "ekologinen tasapaino" - ihmisen ja luonnon suhteen on noudatettava tätä "tasapainoa" ...

"Luonnon tasapainon" ajatus on niin luonnollinen, että se on kai välttämättä tosi. Asia kaipaa kuitenkin täsmennyksiä: Mikä nimenomainen yksikkö luonnossa on tasapainossa? Mikä on tasapainon kriteeri? Miten tasapaino voidaan todeta (tai mitä olisi havaittava, jotta todettaisiin luonnon jonkin osan ei-olevan tasapainossa)? Onko ylimalkaan mahdollista, että luonto ei olisi tasapainossa? ...

\section{1. "Luonnon tasapaino" on vanha uskomus}

"Luonnon tasapainon" aatehistoriaa eritellyt Egerton (1973) ulottaa sen juuret antiikkiin, joskin ekologiaa koskevia jaksoja on kreikkalaisten teksteissä sangen vähän. Eräät elollista luontoa koskevat keskeiset uskomukset palautuvat Platonin dialogiin Timaios. Timaios pitää puheen, jossa hän esittää maailmankaikkeuden synnystä ihmisen fysiologiaan ulottuvan kehityskaaren. Timaios perustelee ensin, että maailmankaikkeus on ainutkertainen mutta tehty jonkin esikuvan mukaan, ja jatkaa sitten (A. M. Anttilan suomennoksena):

"Minkä elävän olennon kaltaiseksi luoja teki maailman? Mielestämme ei ole asian arvon mukaista hyväksyä esikuvaksi sellaista, mikä kuuluu luonnostaan osien luokkaan. Sillä mikään epätäydellisen kaltainen ei voi olla samalla kaunis. Oletamme, että maailmankaikkeus on ennen muuta sen elävän olennon kaltainen, jonka osia kaikki muut elävät olennot sekä yksilöinä että lajeina ovat ... Sillä kun jumala tahtoi luoda maailman kauneimman ja täydellisimmän ajateltavissa olevan kaltaiseksi, hän teki sen yhdeksi ja näkyväiseksi olennoksi, sellaiseksi, joka sisältää kaikki luonnostaan sen itsensä kaltaiset olennot."

Egerton toteaa, että tämä lyhyt katkelma luo perustan kahdelle länsimaisessa perinteessä keskeiselle elollista luontoa koskevalle ajatukselle: Maailma on kuin yksi suuri eliö, joka on eliön tavoin täydellinen ja tasapainoinen (yliorganisminen luonnon tasapainon myytti), ja pieni ja suuri toistavat maailmassa samaa harmoniaa (mikrokosmos-makrokosmos myytti).

Pääasiassa Platoniin palautuu kristillisessä metafysiikassa hallitsevan aseman vallannut ajatus maailmankaikkeudesta "Olevaisen suurena ketjuna" (Lovejoy 1936). Maailmankaikkeus koostuu äärettömästä, hierarkkisesti järjestyneestä ketjusta, joka ulottuu pienimmistä ja vähäpätöisimmistä olioista kaikkien mahdollisten välivaiheiden kautta täydellisimpään ajateltavissa olevaan olentoon asti - josta on kuitenkin vielä ääretön etäisyys absoluuttiin. Maailma on kokonaisuus, joka käsittää kaiken mahdollisen mutta ei mitään liikaa.

Suuressa ketjussa mikään muu kuin harmonia ja tasapaino ei ole mahdollinen. Tämä yleinen ajatusmalli hallitsi käsityksiä eliöiden paikasta maailmankaikkeudessa 1700-luvun lopulle asti. "Biologia" elämää tutkivana itsenäisenä tieteenalana ei ollut vielä muodostunut. Se syntyi vasta $1800-$ luvulla; nimityksen "biologia" otti käyttöön Lamarck. Sitä ennen - Foucaultin (1970) kärjistyksen mukaan - biologiaa ei ollut siitä yksinkertaisesta syystä, että elämää ei ollut, oli vain eläviä olentoja, ja niitä tarkasteltiin luokittelevan luonnonhisto- 
rian käsitteellisen kehyksen läpi.

Luonnonhistoriallisen luokittelun aikakauden suuri nimi oli Linné. Linnén järjestelmän taustalla väikkyy Suuri ketju, joskin sen maallistunut muunnos: Linné koetti yhdistää eliökunnan järjestelmän "luonnon talouteen" (Oeconomia Naturae, 1749), jota hallitsevana periaatteena oli luonnon tasapaino. Egerton korostaa, ilmeisen hyvin perustein, että Linné välitti vanhan, luonnon ykseyttä ja yhtenäisyyttä korostaneen käsityksen modernin biologian ajatusmaailmaan.

\section{2. "Tasapaino" imeytyi ekologiaan "superorganismin" hahmossa}

Ekologia muodostui itsenäiseksi biologisten tieteiden haaraksi Darwinin evoluutioteorian läpimurron mainingeissa. $\mathrm{Ni}$ mityksen otti käyttöön saksalainen morfologi Ernst Hæckel 1860-luvulla viitaten sillä yleisesti "luonnon talouteen". Evoluutioteorian merkitys ekologian taustana on ilmeinen: Kun luonto alettiin mieltää historiallisesti kehittyneenä ja kehitystä ajavia voimia ryhdyttiin etsimään luonnosta itsestään eikä kaitselmuksen säätämästä tuonpuoleisesta, nousivat eliöiden suhteet toisiinsa sekä ympäristöönsä keskeiseksi tutkimuksen kohteeksi.

Hæckelin alkuaskelten jälkeen kului kuitenkin vielä puoli vuosisataa ennen kuin ekologia oli vakiintunut ongelmistaan tietoiseksi tutkimusalaksi. Ekologialle ominaiset tutkimuskohteet täsmentyivät - "luonnon talous", josta Hæckel puhui, on kovin väljä käsite muodostaakseen tieteenhaaran perustan. Näiksi vakiintuivat ekosysteemit ja yhteisöt 1800-luvun lopulla, sekä populaatiot 1920-luvulla. Elollisen luonnon vuorovaikutusten tutkimus alkoi eriytyä, ja vuorovaikutusten näyttämöt selkiytyivät (Haila 1984).
Selkiytyminen teki mahdolliseksi esittää täsmentyviä kysymyksiä myös "luonnon tasapainosta": - Mikä luonnossa on tasapainossa? - Miten tasapaino ilmenee?... Tämän kaltaiset kysymykset kuitenkin heräsivät vasta lähempänä oman vuosisatamme puoliväliä. Alkuvaiheessa tasapainon olettamus oli itsestään selvä, joskin se perusteltiin usein eri tavoin.

Varhaisen ja kiinnostavan muunnoksen esitti yhdysvaltalainen eläintieteilijä Stephen Forbes merkittävässä artikkelissaan "The Lake as a Microcosm" (1887). Otsikon komea metafora ilmentää sitä, että Forbes kiteytti ekologian tutkimuskohteeksi ympäristöstään suhteellisen eristetyt "yhteisöt", joissa luonnon "... kaikki perustavat voimat ovat vaikuttamassa ja elämän näytelmä tapahtuu täydellisenä mutta niin pienessä mittakaavassa, että se helposti mahtuu käsityskykymme piiriin". Forbesin mikrokosmos on vakaassa tasapainotilassa - joskin yksi laji on peto ja toinen sen saalis ja kolmas ja neljäs taas kilpailevat keskenään samasta ravintokohteesta, niin yhteisössä vallitsee "etujen yhteisyys", jonka perustana on kaikkien lajien pyrkimys jatkaa olemassaoloaan; luonnossa kuten kapitalistisessa yhteiskunnassakin "tasapaino" syntyy tuloksena taloudellisten agenttien rajoittamattomasta olemassaolon kilvoittelusta. Niinpä forbesilaiseen mikrokosmokseen "... on syntynyt järjestys, joka on paras ajateltavissa oleva ellei ympäristöoloissa tapahdu täydellistä muutosta".

Järjestelmällisemmän ja käsitteellisesti täsmällisemmän muodon yhteisöjen tasapainoisuuden näkemykselle esittivät vuosisadan vaihteessa kasvillisuuden tutkijat; erityisen vaikutusvaltainen oli yhdysvaltalainen Frederic Clements (Plant Succession, 1916). Näkemyksen mukaan ekologiset yhteisöt ovat "superorganismeja", joilla on yksittäisten organismien tavoin oma 
elämänkaarensa (sukkessio) sekä sisäistä homeostaasia ylläpitävät voimansa. Clementsin vaikutuksesta syntynyt koulukunta hallitsi etenkin kasviekologian kehitystä 1950-luvulle asti, kunnes uuden sukupolven kasviekologit alkoivat järjestelmällisesti verrata clementsiläistä käsitteistöä kasviyhteisöistä koottuun empiiriseen aineistoon (esim. Robert H. Whittaker: A criticism of the plant association and climatic climax concepts, 1951). Kävi ilmi, että yhteisöt eivät lainkaan käyttäydy "superorganismille" soveliain tavoin - clementsiläinen koulukunta ajautui vaikeuksiin, joista se ei ole toipunut.

Vastakohta käsitykselle yhteisöistä "superorganismeina" on ns. individualistinen näkemys: Ekologian keskeisiä yksikköjä ovat yksilöt ja populaatiot, joiden toisistaan poikkeavat ympäristövaatimukset määräävät niiden esiintymisen. "Yhteisöt" ovat tietyllä paikalla sinne osuneiden ja siellä elävien populaatioiden koosteita (engl. "assemblage"). "Individualismia" puolusti esimerkiksi Clementsin ankara opponentti Henry Allan Gleason jo 1920luvulla (The individualistic concept of the plant association, 1926). Hänen näkökantansa jäi häviölle ja painui unhoon noustakseen 50-luvulta lähtien vähitellen uudelleen esiin ja kiteytyäkseen 80-luvulla ekologien valtaosan näkemykseksi.

"Superorganismiin" ei enää moni (kukaan?) alaansa seuraava ekologi usko. Forbesin maalailemaa "etujen yhteisyyttä" ei liioin pidetä mahdollisena, sillä se on ristiriidassa vallitsevan evoluutionäkemyksen kanssa. Perinteisen "ekologisen tasapainon" alta on kadonnut maaperä. Ongelma on kuitenkin seuraava: Jokaisen lajin välittömään elinympäristöön sisältyy välttämättä suuri määrä muita lajeja. Kehittyykö joidenkin lajiparien tai suppeiden lajiryhmien muodostamista ekologisista systee- meistä integroituja kokonaisuuksia? Olisiko näitä kuvattaessa mielekästä puhua "tasapainosta"?

\section{3. "Ekologisen tasapainon" matematiikka on epäilyttävää}

Populaatiotutkimusta painottavaan ekologiaan vakiintui 1950-luvulta lähtien matemaattisia malleja soveltava tutkimusperinne, jonka mallit palautuvat 20-luvulla keksittyihin populaatioiden kasvua ja tärkeimpiä vuorovaikutuksia kuvaaviin yhtälöihin. Populaatiobiologit ovat pyrkineet formalisoimaan ekologisten systeemien tasapainon ehtoja (Lewontin 1969). Sitä eivät vanhan superorganistisen perinteen kannattajat koskaan tehneet (tätä merkillepantavaa seikkaa korostaa erityisesti Egerton, 1973; ennen vanhaan yksinkertaisesti "tiedettiin" ekologisten yhteisöjen olevan tasapainossa).

Tarkastelun lähtökohta lainattiin klassisesta fysiikasta: Ekologiset systeemit tulkittiin vektorikentiksi n-ulotteisessa avaruudessa. Systeemin tilaa tietyllä hetkellä kuvaa piste tässä avaruudessa, ja systeemin kehitystä ajassa pisteen rata. Koko systeemin dynamiikan perusvaihtoehdot saadaan kuvatuksi kun tiedetään, missä avaruuden osissa systeemin tilan kuvaaja on vakaa, missä osissa tilan kuvaaja käy satunnaisesti, ja missä osissa se käyttäytyy syklisesti. Systeemi on "vakaa" sellaisissa vektoriavaruuden pisteissä, joihin systeemin tilan kuvaaja ajautuu kaikilta suunnilta. Systeemi voi olla vakaa joko paikallisesti tai globaalisti - joko jossakin rajoitetussa osassa avaruutta tai koko avaruuden alueella. Näitä vaihtoehtoja on tapana havainnollistaa mekaanisilla analogioilla, esimerkiksi tutkimalla pallon käyttäytymistä kolmiulotteisella pinnalla. Pallo golfkentän keskellä olevassa kuopassa on vain paikallisessa ta- 
sapainopisteessä, mutta kuperan rautapadan pohjalla oleva pallo on globaalissa tasapainopisteessä (jos rautapata käsittää koko avaruuden).

Tämä lähestymistapa voi johtaa fysiikassa kiinnostaviin sovellutuksiin (ammusten lentorata, satelliitit ...), mutta ekologiassa siihen liittyy lukuisia äärimmäisen kiusallisia rajoituksia. Ensinnäkin, n-ulotteisen avaruuden matematiikka hallitaan vain tasapainopisteiden läheisyydessä, missä systeemin muuttujien vuorovaikutussuhteiden voidaan olettaa olevan lineaarisia. Jos tarkastelu halutaan yleistää koskemaan koko avaruutta (eli tutkia systeemin globaalin vakauden ehtoja), on oletettava vuorovaikutukset lineaarisiksi koko avaruudessa. Tämä on ekologiassa ehdottomasti epärealistista; populaatioiden kasvun ja vuorovaikutusten tiedetään olevan epälineaarisia.

Toiseksi, on erittäin vaikeata kuvitella nulotteiselle vektorisysteemille uskottavia ekologisia vastineita. Tämä kysymys on tietenkin empiirinen ja palautuu osittain clementsiläisen "superorganismin" kritiikkiin. Jos yhteisöt todella olisivat suljettuja "superorganismeja", niistä ehkä olisi myös vektoriavaruuksiksi - mutta kun ne eivät ole.

Lisäksi matemaattinen tasapainotarkastelu tuottaa inhottavan paradoksin: Tasapainossa olevalla systeemillä ei ole historiaa, koska on samantekevää, miten se on tuohon tilaan päätynyt. Systeemin kuvaukseksi riittää, että tunnistetaan oikeat muuttujat ja tunnetaan parametrien arvot. Ekologisilla systeemeillä kuitenkin on historia, ja mitä enemmän ekologiasta tiedetään, sitä enemmän historian merkitys korostuu.

Ekologisiin systeemeihin luo historiaa sattuma. Systeemien tilaan vaikuttaa tekijöitä, jotka ovat systeemeistä itsestään riippumattomia ja niiden sisäisten suhteiden pohjalta ennakoimattomia. Sattuma ilmenee useassa eri muodossa. Äärimmäisen harvinaiset suuret luonnonkatastrofit ovat ainutkertaisia. Luonnon valintaan perustuva evoluutio ei mitenkään voi tuottaa sopeutumia miljoonien vuosien välein tapahtuvien katastrofien varalta. Toinen sattuman muoto on ennustamattomuus. Sitä edustavat esimerkiksi metsäpalot luonnontilaisessa taigassa. Paloilla on keskimääräinen esiintymistaajuus, mutta palon sattuminen Marjosenvaarassa vuonna 1533 oli "sattuma". Metsäpalojen ennustamattomuuteen taigan kasvi- ja eläinlajit ovat evolutiivisesti sopeutuneet (ehtona on, että palojen välinen keskimääräinen aika on lyhyempi kuin lajien perimän "muisti"). Sattumaa on myös stokastinen vaihtelu systeemiin vaikuttavissa tekijöissä, esimerkiksi sääolosuhteissa. Edelleen eräs ekologisen sattuman muoto on kontingenssi, toisistaan riippumattomien kehityslinjojen satunnainen kohtaaminen. Pohjois-Euroopan metsien nykyinen puulajikoostumus on kontingentti, koska se on syntynyt viimeisimpien jääkausien aikaisten, lajeittain vaihdelleiden levinneisyysalueiden heilahtelujen tuloksena.

Ongelma on, kuinka nopeasti satunnaisten häiriöiden, järkytysten ja mullistusten jälkeen systeemin "tasapaino" palautuu. Jospa satunnaiset häiriöt eri muodoissaan ovatkin sääntö eikä poikkeus ...

Tasapainomatematiikasta johdettu näkemys ekologisten systeemien vakaudesta on suurissa vaikeuksissa. On erittäin kyseenalaista, onko tasapainomalleille luonnossa vastineita.

\section{4. "Tasapaino" vastaan "palautuvuus"}

Tasapainotarkasteluille onkin esitetty ekologiassa vaihtoehtoja. Erään tärkeimmistä käsitteiden täsmennyksistä esitti C. S. Hol- 
ling (1973). Holling esitti, että ekologisten järjestelmien rakenteellista pysyvyyttä luonnehtii "vakauden" ohella toinen, tärkeämpi ominaisuus, "palautuvuus" (engl. "resilience"). "Vakaa" systeemi pysyy tasapainoisena vastustamalla muutoksia, mutta "palautuva" absorboi ulkopuoliset muutokset ja häiriöt siten, että systeemin sisäiset vuorovaikutukset säilyvät ennallaan vaikka systeemin hetkellinen tila muuttuisi rajustikin. Palautuvuuden ajatusta voidaan heuristisesti perustella peliteoreettisella tulkinnalla evoluutiosta (Slobodkin 1964): Evoluutio tulkitaan eri lajien väliseksi peliksi, jossa voittajien palkinto on pysyä mukana, hävinneet ajautuvat sukupuuttoon. Ekologisten systeemien pysyvyyden voidaan ajatella seuraavan siitä, että jokainen pelissä säilyvä laji yksittäin ottaen välttää sukupuuton (mikä on eri asia kuin Forbesin "etujen yhteisyys").

Palautuva systeemi ei välttämättä ole vakaa. Esimerkiksi metsäpalojen aika ajoin polttama kaistale taigaa on "palautuva", siihen kasvaa aina ajan mittaan uusi metsä, mutta "vakaaksi" sitä on vaikea mieltää.

Holling väitti, että "palautuvuus" on sekä teoreettisesti että käytännöllisesti tärkeämpi ekologisten systeemien ominaisuus kuin "vakaus". Ei kannata tuijottaa ekologisten yksiköiden "tasapainoon" tässä ja nyt vaan kiinnostua niiden "palautuvuudesta" pidemmässä aikamittakaavassa ja laajemmalla alueella. Ekologisten systeemien mittakaavan merkitys korostuu aivan kuten yksittäisten populaatioidenkin (kts. Hanski, tässä numerossa). Historia nousee palautuvuuden myötä ekologian näyttämölle. Ylivoimainen valtaosa maapallolla eläneistä lajeista on ajautunut sukupuuttoon, mikä mistäkin syystä, mutta nykyiset pelaajat jatkavat peliä.

"Ekologiselle tasapainolle" on heitetty hyvästit niin teoreettisena kuin käytännöllisenäkin ihanteena. Edessä on seuraava tehtävä: tutkia ekologisten systeemien $p a$ lautuvuuden yleisiä ehtoja.

\section{5. "Palautuvuus" ja systeemien reunaehdot}

Ekologisten systeemien palautuvuudesta tiedetään toistaiseksi valitettavan vähän $\mathrm{mm}$. siksi, että alan teoriaa hallitsi pitkälle 70-luvulle tasapainomatematiikka, joka nykypäivän katsannosta on mielenkiinnotonta ja mitä ilmeisimmin virheellistä. Palautuvuus liittyy systeemin reunaehtojen pysyvyyteen, kuten jo Holling esitti. Nämä reunaehdot käsittävät ympäristön fysikaalisia ja kemiallisia peruspiirteitä, joiden vallitessa kunkin lajin evoluutio on tapahtunut. Mutta reunaehtojen olennaisen osan muodostaa myös kullekin ympäristötyypille ominainen olosuhteiden vaihtelun mittakaa$v a$ niin ajassa kuin tilassakin. Muutos on luonnossa universaalia. Tämän merkitystä ekologisen teorian kannalta ei luultavasti tajuta vieläkään. Luonnossa ei ole muuttumattomia systeemeitä, ei pieniä eikä suuria. Siksi ekologisten systeemien rakenteellisen pysyvyyden kannalta olennaisinta on, millaisiin ympäristön muutoksiin niissä elävät lajit ovat sopeutuneet, miten systeemit ovat historiansa kuluessa rakenteeltaan vaihdelleet.

Ottakaamme jälleen esimerkiksi taiga. Luonnontilaisessa pohjoisessa havumetsässä metsäpalot ovat toistuneet noin sadan vuoden välein - kuivilla metsätyypeillä hiukan tiheämmin, kosteilla harvemmin. Taigan lajisto on evolutiivisesti sopeutunut tähän metsäpalokiertoon: Oivallisia sopeutumia ovat esimerkiksi monien hyönteisten hyvä leviämiskyky, jonka avulla löytää (todennäköisesti) soveliaan ikäisen metsikön; tai metsän yleislajien kyky tulla toimeen monenikäisissä metsissä; tai monien kas- 
vien kyky "talvehtia" metsäkierron epäsuotuisten vaiheiden yli maaperässä siemeninä tai juurakoina.

Asia on käytännössä mitä tärkein esimerkiksi arvioitaessa metsätalouden vaikutuksia metsäluontoon. Ei ole kiintoisaa todeta, että Kurkikankaan lajisto muuttuu kun vanha metsä hakataan avoimeksi näin on Kurkikankaalla tapahtunut luonnontilassakin tämän tästä metsäpalojen seurauksena. Olennaista on, eroaako nykyinen metsäluonnon häiriintymisen kierto luonnontilaisesta kestoltaan tai laajuudeltaan, tai muuttaako metsätalous metsän rakennetta kierron jossakin vaiheessa.

Eroja on, ja niistä johtuen osa metsäluonnosta on uhanalaista. Eräitä metsälajeja uhkaa sukupuutto, koska niiden vaatima metsän osa, lahoava puu, poistetaan talousmetsistä (lahopuussa elävät hyönteiset). Toinen ryhmän metsälajeja on vaikeuksissa, koska metsätalouden käsittelyyksiköt ovat laajempia ja yhdenmukaisempia kuin luonnonkulojen mosaiikkimaisesti eri-ikäiset palolaikut (pohjoisessa taigassa talvehtivat paikkalinnut kuten metso, lapintiainen ja kuukkeli). Metsäluonnon palautuvuus on voimaperäisen metsätalouden alueilla uhattuna, mutta "tasapainolla" ei ole tämän asian kanssa mitään tekemistä.

Sama päättely soveltuu nykyajan vakavimpaan luonnonsuojelun ongelmaan, trooppisten sademetsien hävittämisestä seuraavaan sukupuuttoaaltoon. Myös sademetsien lajisto on sopeutunut ympäristön jatkuviin muutoksiin ja häiriöihin mutta hyvin pienessä mittakaavassa. Metsätaloudesta ja hampurilaiskarjan kasvatuksesta syntyvät häiriöt ovat sekä kestoltaan että laajuudeltaan useita kertaluokkia luontaisia suurempia. Useimpien sademetsän lajien on täysin mahdotonta selvitä niistä.

On mahdollista, että ekologinen systeemi siirtyy uuteen tilaan, kun sen reunaehdot muuttuvat. Uusi tila voi olla "palautuva" kuten entinenkin. Ilmiö on toistuvasti havaittu esimerkiksi ylikalastuksen yhteydessä: Liiallisen pyynnin romahduttama kalakanta ei välttämättä alakaan kasvaa vaikka pyynti lopetettaisiin, koska koko

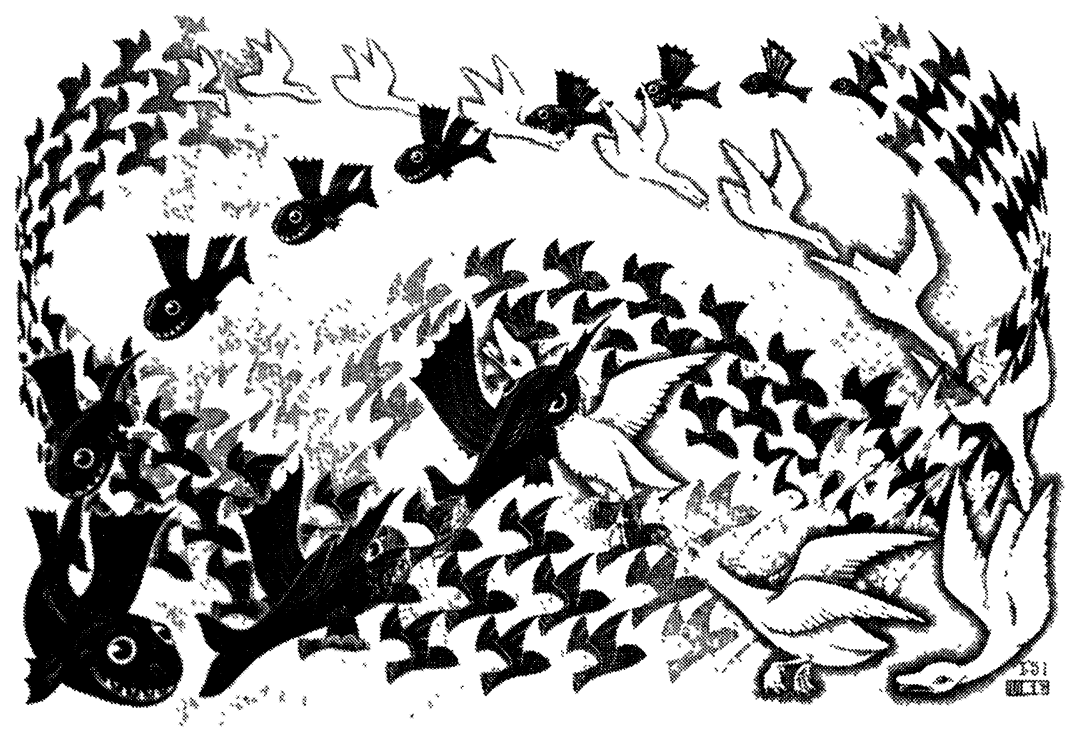


systeemi on ylikalastuksen seurauksena siirtynyt uuteen tilaan. Tämä tulos voidaan perustella myös tasapainomatematiikalla: Voidaan ajatella, että systeemin mahdollisten tilojen avaruus jakautuu useaan osaan, joista jokaisessa on oma tasapainopisteensä.

Saastuminen vaikuttaa usein ekologisiin systeemeihin siten, että niiden "palautuva tila" muuttuu. Esimerkiksi Etelä-Suomen maanviljelysseutujen järvissä yleistyneiden sinileväkukintojen mekanismi on tällainen. Taustana on vuosikymmeniä jatkunut, etupäässä peltojen keinolannoituksen hajakuormituksesta johtuva ravinteisuuden nousu. "Yhtäkkiä" sinilevät runsastuvat räjähdysmäisesti: Vielä vuosi pari sitten vesiensuojeluyhdistyksen miehet arvioivat vesistön tilan vähintäänkin tyydyttäväksi, jopa hyväksi ... mutta tänä kesänä se on sameaa, öljymäisen kalvon peittämää ja allergiareaktioita aiheuttavaa lientä.

Järven ekologinen systeemi on siirtynyt uuteen tilaan, joka valitettavasti on "palautuva". Siksi järveä on tavattoman vaikea ennallistaa alkuperäisekseen. Uusi tila on aivan yhtä "tasapainoinen" kuin vanhakin, ja sinilevät ovat yhtä "luonnollisia" organismeja kuin niiden syrjäyttämä vähäravinteisten vesien lajisto. Järven palautuvuuden reunaehdot sen sijaan ovat oleellisesti muuttuneet.

Saastumisen vaikutukset ovat tyypillisesti hiipiviä: Alkuvaiheessa ekologisen systeemin palautuvuus säilyy, mutta kun siirrytään jonkin raja-arvon yli, systeemi muuttuu täysin muuksi. Esimerkkejä tarjoutuu mielin määrin kaikilta mantereilta.

"Tasapaino" ei ole tällaisten muutosten yhteydessä kiinnostavaa, koska sekä uusi että vanha tila ovat yhtäläisen tasapainoisia (tai tasapainottomia). On järkevämpää kiinnittää huomio palautuvuuden reunaehtoihin.

\section{6. "Tasapainosta" ei ole argumentiksi}

Maapallon luonto on inhimillisen toiminnan seurauksena suurten muutosten edessä. Niiden ekologisia seurauksia arvioitaessa "tasapaino" on kuitenkin huono mittapuu, sillä:

(1) On kyseenalaista, ovatko ekologiset systeemit tasapainossa. Evolutiivisesti tärkeä systeemien ominaisuus on palautuvuus, joka usein (useimmiten?) perustuu systeemien tilan paikallisiin suuriin vaihteluihin, siis epätasapainoon.

(2) Suhteellisen muuttumattomina pysyvillä ekologisilla systeemeillä on mitä todennäköisimmin (aina?) vaihtoehtoisia "palautumistiloja", eikä ole mitään ekologista kriteeriä valita näiden välillä.

(3) "Tasapainosta" ei ole edes kelvolliseksi metaforaksi, koska se kiinnittää huomion paikallisten systeemien muuttumattomuuteen (joka on epärealistista) eri mittakaavoissa tapahtuvan jatkuvan muutoksen sijasta (joka on elollisen luonnon olotila).

Uskoa luonnon tasapainoon on kuin uskoisi jumalaan: Hänen ideansa on kaikkialla läsnä vaikkei olekaan maallisissa kappaleissa välittömästi ilmenevä.

\section{Entä luonnon kokonaisuus?}

Vaikka tasapainoa onkin vaikea löytää mistään yksittäisistä ekologisista systeemeistä, niin eikö maapallon elämä kokonaisuudessaan kuitenkin ole ympäristönsä kanssa harmonisessa tasapainossa? Tällaista ajatusta tavoittelee Jim Lovelockin (1979) hypoteesi "Gaia - äiti maa". Hypoteesin perustelu on se, että elämä on evoluutionsa aikana muuttanut maapallon olosuhteita ja näin on syntynyt suuri, harmoninen, koko maapallon käsittävä järjestelmä.

Ajatusta on vaikea uskoa useasta syystä: 
Ensinnäkin, elävät organismit ovat toki oleellisesti vaikuttaneet esimerkiksi ilmakehän koostumukseen, mutta tästä ei tietenkään mitenkään seuraa, että kyseessä olisi integroitu ja tasapainoinen systeemi. On erityisen vaikea uskoa ilmakehän tasapainoisuuteen siksi, että ilmakehän koostumuksessa on tapahtunut geofysikaalisen aineiston mukaan suuria vaihteluja. Vaihtelu lienee yhteydessä $\mathrm{mm}$. paleontologisen aineiston osoittamiin sukupuuttoaaltoihin. On täysi arvoitus, miten nämä saisi sovitetuksi yhteen Gaia-hypoteesin kanssa. Edelleen, darwinistista käsitystä evoluution mekanismeista on mahdoton sovittaa yhteen sen ajatuksen kanssa, että elämä maapallolla kehittyisi yhtenäisenä kokonaisuutena. Evoluution yksiköitä ovat populaatiot, ja evoluutio on opportunistista populaatiotasolla - korkeamman asteiset harmoniset kokonaisuudet sortuvat siihen, että joku vetää välistä.

Elämä kokonaisuutena rajautuu hedelmällisemmin reunaehdoistaan. Näköpiirissämme on monta mahdollista tapaa muuttaa elämän reunaehtoja koko maapallolla siten, että elämän "palautuvuus" on radikaalisti uhattuna. "Gaiaa" voi pitää kauniina vertauskuvana vastuustamme elämän yleisten reunaehtojen suhteen, mutta tasapainomalliksi siitä ei ole.

\section{Entä "ihmisen ekologia"?}

Eräs tapa etsiä ehdotonta mittapuuta ihmisen ja luonnon suhteen ihanteelliselle järjestelylle on tulkita ihminen yhdeksi eläinlajiksi ja ottaa ihmisen biologiset tarpeet, "ihmisen ekologia" kaiken lähtökohdaksi. Mutta jälleen joudutaan vaikeaan hetteikköön:

Ensinnäkin, mihin ihmisen piirteisiin ekologiset lainmukaisuudet pätevät? Tämä ei ole laisinkaan selvää. Perustekijät, joiden avulla eläinten ja kasvien populaatioi- den kohtaloita tarkastellaan, ovat ihmisellä historiallisesti muuttuvia ja sosiaalisesti eriytyviä (ravinto, lisääntyminen, sairastavuus ...). Ihminen on yhteiskunnallisuutensa lävistämä, ja ekologia -luonnontieteen anti ihmisen spesifien elinehtojen määrittämiseen on kyseenalainen.

Toiseksi, luontoa koskevat käsitykset ja ihanteet ovat vahvasti kulttuurisia, kuten Raymond Williams (1980) on hienosti osoittanut. On mahdotonta löytää mistään historiallisesta vaiheesta "ihmiselle luontaisen" luonnon esikuvaa - historiasta löytyy vain kullekin aikakaudelle ominaisia ihanteita, jotka kuoriutuvat toistensa sisältä kuin venäläiset nuket. Luonnollisen luonnon ihanteet ovat kaikki yhtä mielivaltaisia.

Ihmisen "luonnollisten tarpeiden" arvioinnin erityisen kiero vaikeus on siinä, että pitää ensin päättää, onko ihminen osa luontoa ja siis "luonnollinen" vai ei. Jos hän on, miksei kaikki ihmisen tekemä ole "luonnollista"? Jos hän ei ole, pitäisi määritellä, missä vaiheessa ihmisen luonnottomuus on alkanut. Syntiinlankeemus on tästä eräs tulkinta, mutta ei loppuun asti uskottava.

\section{Luonnon kulttuurista määräytymistä ei pääse pakoon}

Etsittäessä luonnosta ohjenuoraa ihmisen elon ja olon järjestelylle törmätään luonnon kulttuurisuuteen kaikilla tasoilla: Luonnon kuva on kulttuurin läpitunkema jo ennen kuin luontoon on luotu silmäystäkään. Luonto nähdään sellaisena kuin sen kuvitellaan olevan. Luonnontiede tietenkin vaikuttaa tähän kuvitelmaan, ja sillä on yksityiskohdissa analyyttistä voimaa, mutta tieteen pohjana on kaikkea yhteiskunnallista ajattelua hallitseva kulttuuriperintö. Foucault'n jälkeisinä aikoina tätä on vaikea kiistää. 
Ekologian alalla erinomainen esimerkki on Luonnon tasapainon tarina. Luonnon on oletettu olevan tasapainossa, koska sen on tiedetty olevan tasapainossa. Sen on tiedetty olevan tasapainossa, koska on mahdotonta kuvitella sen olevan muuta kuin tasapainossa.

\section{0. 'Tasapainon" hälvettyä suojelun haasteet jä̈̈vät}

Tasapainon hajoaminen ei merkitse sitä, että joutuisimme hyväksymään kaiken inhimillisen toiminnan luonnon suhteen kaikissa tilanteissa yhtä oikeutetuksi ja mielekkääksi. Luonnon palautuvuuden vaaliminen esittää toiminnalle ohjenuoria, esimerkiksi seuraavanlaisia:

(1) Koska muutos on luonnon olotila, on siihen varauduttava. Paikallisten systeemien vakaus ei ole mielekäs tavoite, systeemien pysyvyys riippuu muutossykleistä laajoilla alueilla.

(2) On vältettävä peruuttamattomia muutoksia. Evolutiivisesti peruuttamaton tapahtuma on sukupuutto; jokainen sukupuutto, minkä lajin tahansa ja missä tahansa, on koetettava estää.

(3) On varottava ekologisten systeemien reunaehtojen muuttumista niin paikallisesti kuin maapallon laajuisestikin.

Loppu, esimerkiksi valinta kirkasvetisten tai sinileviä kukkivien järvien välillä, on kulttuuria. Suureen osaan ympäristöongelmia on mahdotonta luonnosta käsin johtaa ratkaisuja. Ihmisen ja luonnon suhde ei ratkea "alkuperäisen luonnon" ihanteen varassa, koska maapallolla ei enää vuosituhansiin ole ollut ihmisen vaikutuksesta vapaata kolkkaa.

Ihmisen ja luonnon suhde rakentuu läpikäyvästi kaikkialla, mutta erityisesti siellä, missä ihmiset elävät - kaupungeissa, kulttuurin keskellä. Luonto ihmisen välittömässä ympäristössä ei ole saastaista. Rä- kättirastaat ovat yhtä luonnollisia Esplanadin puistossa kuin Sodankylän rämeillä. Niiden kulttuuriset määritykset ovat erilaisia, mutta eivät ne itse tiedä eroa eikä se niitä kiinnosta. Ihminen on ainoa olento, jota se kiinnostaa.

Elämme haarautuvien polkujen puutarhassa. Harmaapartainen vanhus pilven reunalla lakkasi aikoja sitten näyttämästä tietä. Myös ekologian karttakirja on repeytynyt riekaleiksi jääkausien, taivaalta putoilevien isojen kivien, metsäpalojen ja mannerlaattojen liikuntojen ryskeessä. On ratkaistava asioita aivan itse, yksi kerrallaan, ilman kaitselmuksen tai maailmankaikkeuden pohjapiirroksen apua. On itse valittava suunta, pystytettävä tienviitat.

"Matkan päästä, maiseman läpi

kuuluu hiljaa mutta selvästi

keväinen lähde.

Minä kuuntelen,

lähden menemään sinnepäin. ..."

(Bo Carpelan: Lähde/Elämää jota elät; suom. Tuomas Anhava)

\section{Kirjallisuus}

Egerton, F. N. (1973). Changing concepts of the balance of nature. Quart. Rev. Biol. 48, 322-350.

Foucault, M. (1970). The order of things. Tavistock, London.

Haila, Y (1984). The development of ecology and social practice. In: Humanity and nature, Tutkijaliitto, 5-15.

Holling, C. S. (1973). Resilience and stability of ecological systems. Annu. Rev. Ecol. Syst. 4, 1-23.

Lewontin, R. C. (1969). The meaning of stability. Diversity and stability of ecological systems. Brookhaven Symp. Biol. 22, 13-24.

Lovejoy, A. O. (1936). The great chain of being. Harvard Univ. Press, Cambridge, Mass.

Lovelock, J. (1979). Gaia. A new look at life on earth. Oxford Univ. Press, Oxford.

Slobodkin, L. B. (1964). The strategy of evolution. Amer. Sci. 52, 342-357.

Williams, R. (1980). Problems in materialism and culture. Verso, London. 